\title{
Vocal Fatigue and Voice-Related Quality of Life in Korean Speech-Language Pathologists
}

\author{
Ji Sung Kim ${ }^{\mathrm{a}, \mathrm{b}}$, Seong Hee Choi ${ }^{\mathrm{a}, \mathrm{c}}$ \\ ${ }^{a}$ Graduate School of Daegu Catholic University, Gyeongsan, Korea \\ ${ }^{b}$ Department of Otorhinolaryngology, Chungbuk National University Hospital, Cheongju, Korea \\ 'Department of Audiology and Speech-Language Pathology, Daegu Catholic University, Gyeongsan, Korea
}

\author{
Correspondence: Seong Hee Choi, $\mathrm{PhD}$ \\ Department of Audiology and Speech-Language \\ Pathology, Daegu Catholic University, 13-13 \\ Hayang-ro, Hayang-eup, Gyeongsan 38430, Korea \\ Tel: $+82-53-850-2542$ \\ Fax: $+82-53-850-2540$ \\ E-mail: shgrace@cu.ac.kr
}

Received: July 8, 2018

Revised: November 1, 2018

Accepted: November 23, 2018

This work is supported by 2017 Capacity Development project from the Korean Association of Speech Language Pathologists.

\begin{abstract}
Objectives: The purpose of this study was to investigate the vocal fatigue, voice-related quality of life, and their related factors in Korean speech-language pathologists (SLPs) for the improvement of voice health. Methods: A total of 137 SLPs (male 20, female 117) responded to an online or offline survey and then the data were analyzed. The respondents worked 20 sessions per week. Seventy-nine of the participants were in their 20s, 46 in their 30s, and 12 in their 40s and above. Results: SLPs who had subjective problems showed significantly higher K-VQOL-physical functional, K-VQOL-social-emotional, K-VQOL total, KVFI-fatigue, K-VFI-physical, K-VFI-rest, and K-VFI-total ( $p \leq .001)$. Additionally, K-VQOL and KVFI based on workplace, sessions per week, and career were not significantly different. There was a significant correlation $(p \leq .000)$ between subjective voice symptoms, voice abuse and misuse, voice fatigue index and voice-related quality of life. The type of workplace where the highest percentage of SLPs worked for over 40 sessions was the hospital (10.9\%). Conclusion: To reduce vocal fatigue and to improve voice-related quality of life of SLPs, vocal abuse and misuse that may affect voice problems should be eliminated and also self voice care need to be implemented in their daily life. These findings may help SLPS improve not only voice health but also overall life satisfaction and job satisfaction.
\end{abstract}

Keywords: Speech-language pathologist, Vocal fatigue, Voice-related quality of life
음성피로는 청지각적(perceptual), 음향학적(acoustic), 생리학적 (physiologic) 측면에서 후두의 기능이 부정적으로 변화되는 것을 의미하는 것으로(Welham \& Maclagan, 2003), 생리학적으로 후두 근육피로(laryngeal muscle fatigue)와 후두조직피로(laryngeal tissue fatigue)의 측면에서 설명할 수 있다. 후두근육피로는 잠재적으 로 음성남용에 의한 근육의 생리에서 화학적인 측면의 불균형에 의해 발생되는 근육의 수축을 제거하거나 짧은 시간에 근육수축 의 강도와 속도를 줄이기 위해 발생되는 것을 의미하고, 후두조직 피로는 진동외상이라고도 불리는 과도한 성대진동으로 인한 점막 고유층(lamina propria)의 일시적인 변화나 손상으로 인한 것을 의 미한다(Hunter \& Titze, 2009). 또한, 음성피로는 여러 가지 복잡한 다면적인 임상적 현상으로 일정 기간의 음성 사용 후에 국소적 피 곤이나 약한 음성의 느낌이나(Verdolini, Rosen, \& Branski, 2006;
Welham \& Maclagan, 2003), 음성과 관련된 부정적 감각을 포함한 자가 인식 상태로서(Vilkman, 2004), 말하는 동안 혹은 말한 후 증 가된 노력성 발성, 후두의 불편감, 목과 어깨 긴장과 통증, 음도 범 위 및 음성 강도의 감소, 목소리 유연성 감소, 감소된 음량과 조절, 휴식 시 증상 개선, 음성 상실과 같은 다양한 증상을 포함한다(Solomon, 2008; Welham \& Maclagan, 2003). 음성피로의 신경생리학 적, 발성학적 특성으로 쉬거나 거친 음질, 말하는 동안 호흡의 소 진, 기식성 발성, 불완전한 음성, 어깨나 목의 긴장, 음성 상실, 음도 일탈, 목과 어깨 통증, 편안한 음도를 유지하기 어려움, 감소된 음도 와 강도 범위, 목의 조임과 협착, 삼킴 중 통증, 소리 전달력의 감소, 기침이나 헛기침 필요의 증가, 노력성 발성, 목의 피로감, 목의 뒷부 분이나 가슴의 통증 등이 있다(Kostyk \& Rochet, 1998). 이처럼 음 성피로는 자기 스스로 자각할 수 있을 뿐 아니라, 관찰 가능한 상태 
를 말하며 음성피로현상과 관련된 요인에 관한 조사로는 성별, 음 성위생, 음성 훈련 여부, 직업과 관련된 음성 요구도 등에 따라 영향 을 미친다(Gelfer, Andrews, \& Schmidt, 1991; Scherer et al., 1987). 이 처럼 음성피로현상에 영향을 주는 요인은 다양하며 개인 간 민감 도 또한 다양하다.

언어재활사는 업무상 지속적인 음성사용이 요구되며 음성의 문 제가 일을 적절히 유지하는 데 방해가 되는 직업적 음성사용자 (professional voice user)이며, 음성사용이 많은 직업인이나 일반 직 업인에 비해 음성문제와 관련된 경험이 많고, 음성장애를 느끼는 주관적 정도에 따른 음성 증상 유병률이 $61.6 \%$ 로 다른 직업군보다 높다(Song \& Pyo, 2010). 최근 연구에 의하면, 187명의 언어재활사 중 $33 \%$ 가 만성적인 음성문제를 호소하며, 언어재활사 중에서도 음 성문제가 있는 집단이 음성문제가 없는 집단에 비해 음성장애지수 가 통계적으로 유의하게 더 높은 것으로 나타났다. 또한, 주관적인 만성적 음성문제가 있는 언어재활사는 문제가 없는 언어재활사에 비해 '큰 소리로 말하기', '시끄러운 환경에서 말하기', '오랜 시간 동 안 말하기', '먼지 나는 곳에서 말하기', '자신의 음역보다 지나치게 높거나 낮은 상태로 말하거나 노래하기', '헛기침/목청 가다듬기'등 의 음성오남용의 빈도와 음성장애지수가 더 높았다. 언어재활사가 호소하는 주관적인 음성 증상으로는 음성피로감(55.6\%), 쉰 목소 리(50.3\%), 말할 때 힘이 들어감(49.2\%), 거친 음성(41.7\%), 말할 때 통증 $(35.3 \%)$, 말할 때 힘이 듦( $28.3 \%, 53$ 명), 노래에서 고음 발성 곤 란(23.5\%, 44명) 순으로 음성피로와 관련된 증상이 가장 많았으며, 이로 인해 치료 회기 수를 줄이거나 휴식의 필요성을 느끼는 것으 로 나타났다(Kim \& Choi, 2018). 이처럼 언어재활사의 음성문제는 음성피로와 관련된 증상이 많은데, 이는 언어재활사 개인의 삶의 질뿐 아니라 치료 서비스의 질과 효과로 이어질 수 있는 문제이기 때문에 언어재활사의 주관적인 음성피로도를 조사하고 음성피로 에 영향을 미치는 요인을 규명함으로써 언어재활사의 직업적 만족 도와 음성과 관련된 삶의 질을 높이는 것이 필요하다(Kim \& Choi, 2018; Koufman \& Isaacson, 1991; Song \& Pyo, 2010).

이러한 직업적 음성 사용과 관련한 음성피로의 중증도 및 일상 생활에서 음성이 삶에 미치는 영향과 이에 관련된 요인들을 측정 하기 위하여 음성과 관련된 삶의 질 검사(Voice-Related Quality of Life, V-RQOL; Hogikyan \& Sethuraman, 1999) 및 음성피로도 검 사(Vocal Fatigue Index, VFI; Nanjundeswaran, Jacobson, Gartner-Schmidt, \& Abbott, 2015)가 개발되어 사용되고 있다. 이러한 검사는 객관적인 음성검사에서 밝혀 내지 못하는 음성 사용과 관 련된 다양한 개인의 신체적, 정서적, 기능적 요인들에 대한 정보를 제공해 준다. Kang, Chang과 Koo (2017)에서 음성피로도의 점수
가 높을수록 기본주파수와 기본주파수의 편차, 음성일탈과 음성 진전이 증가하는 반면 음도와 강도의 주기성과 청지각적인 음질은 저하되었으며, 평균 음압과 최대연장발성지속시간은 감소하며 $\mathrm{VHI}$ 와 정적 상관을 보였다.

따라서, 본 연구는 한국언어재활사의 직업적 음성사용실태를 파 악하고, 직업적 음성사용자로서 언어재활사 개인이 각 임상환경에 서 느끼는 음성피로 및 음성과 관련된 삶의 질 특징을 살펴보고, 언 어재활사의 음성피로 및 음성에 영향을 주는 다양한 요인들을 찾 아내어 언어재활사의 음성건강 증진에 도움을 주고자 한다.

\section{연구방법}

\section{연구대상}

본 연구의 대상자는 정상적인 말이나 음성산출에 영향을 미칠 수 있는 소화기계나 내분비계, 신경계의 질환 혹은 정신과적 질환, 청각장애나 알레르기성 장애가 없고, 상기도 건조나 점막의 분비 를 저하시킬 수 있는 경구용 피임약이나 갑상샘 질환, 호르몬 계통 의 약물 및 알레르기와 관련된 항 히스타민제와 같은 약물(Sataloff, Hawkshaw, \& Rosen, 1997)을 복용하지 않는 한국인 언어재활 사 137 명이다. 연구대상자의 성별은 남 20명(14.6\%), 여자 117명 (85.4\%)이며, 대상자의 연령은 20-29세 79명(57.7\%), 30-39세 46명 (33.6\%), 40 세 이상이 12명(8.7\%)이고, 주당 치료 수는 20 회기 이상 으로 20-29회기가 60명(43.8\%), 30-39회기가 51명(37.2\%), 40회기 이상이 26명(13.9\%)이다(Table 1). 대상자의 학력은 전문대 졸 2명 (1.5\%), 대학 졸 76명(55.5\%), 학부 비전공 석사 졸 16 명(11.7\%), 학부 전공 석사(수료/졸업) 39 명(28.5\%), 박사(재학, 수료, 졸업) 4 명(2.9\%) 이며, 대상자의 근무기관은 사설센터가 90 명(65.7\%), 병원 28명 (20.4\%), 복지관 15 명(10.9\%), 기타 4 명(3\%)이었다.

Table 1. Participants' information

\begin{tabular}{lr}
\hline Characteristic & $\mathrm{N}(\%)$ \\
\hline Sex & \\
Male & $20(14.6)$ \\
Female & $117(85.4)$ \\
Age (yr) & \\
20s & $79(57.7)$ \\
30 s & $46(33.6)$ \\
40 s+ & $12(8.7)$ \\
Sessions per week & \\
$20-29$ & $60(43.7)$ \\
$30-39$ & $51(37.2)$ \\
$40+$ & $26(19.0)$ \\
\hline
\end{tabular}




\section{설문지}

설문지는 임상가의 경험과 선행연구(Song \& Pyo, 2010)를 참고 하여 개발하였으며, 언어병리학과 음성장애 전공교수 1 명과 10 년 이상 음성장애 임상경험이 있는 1 급 언어재활사 2명(임상경력 13.2 $\pm 5)$ 에게 설문의 내용에 대한 피드백을 받아 최종적으로 완성하 였다. 설문내용은 성별, 연령, 근무경력, 주당 세션 수, 근무기관, 학 력 등과 같은 기본적인 개별정보(Appendix 1)와 주관적인 만성적 음성문제 여부와 14 개의 주관적인 음성증상, 음성문제로 인한 휴 직경험이나 휴식의 필요성, 이비인후과 진료경험과 치료내용에 관 한 내용(Appendix 2) 및 음성위생에 관한 대한 지식과 수행 여부에 관한 내용(Appendix 3)으로 구성하였다. 이 외에 '소리 지르기, 큰 소리로 말하기, 오랜 시간 동안 말하기, 시끄러운 환경에서 말하기, 과도한 말하기나 이야기하기, 먼지 나는 곳에서 말하기, 속삭이기, 지나치게 크게 울거나 웃기, 노래 부르기, 자신의 음역보다 지나치 게 낮거나 높은 상태로 노래하거나 말하기, 흡연, 알코올섭취, 카페 인(커피, 녹차, 탄산음료 포함)섭취, 기침이나 목청 가다듬기'를 4점 척도(안 함, 가끔, 보통, 자주)로 평가하는 Choi와 Choi (2013)의 음 성오남용 체크리스트와 한국판 음성과 관련된 삶의 질(Korean version of Voice-Related Quality of Life, K-VQOL; Kim et al., 2007), 한국판 음성피로도 검사(Korean version of Vocal Fatigue Index, KVFI; Cho, 2016; Kang et al., 2017)를 설문 내용에 포함하였다(Appendix 4).

음성피로지수 검사는 환자 자신이 음성피로에 대해 느끼는 정도 를 평가하는 주관적인 검사로 총 19문항으로 음성회피 및 피로, 음 성사용 시 신체적 불편, 휴식 후 음성향상에 관련된 3가지 영역으 로 구분되어 있다. 평가는 $0-4$ 점 체계로 ' $0=$ 결코 없다, $1=$ 거의 없 다, $2=$ 때때로 있다, $3=$ 거의 항상 있다, $4=$ 항상 있다'이며 0 점에서 76점까지 가능하다. 점수가 높을수록 음성으로 인한 주관적으로 느끼는 음성피로지수가 높다고 평가한다(Nanjundeswaran et al., 2015). 본 연구에서는 Cho (2016)의 한국어판 음성피로도 검사(K$\mathrm{VFI}$ )를 사용하였다.

음성과 관련된 삶의 질 검사는 Hogikyan과 Sethuraman (1999) 에 의해 개발된 주관적 검사도구로서 목소리가 일상생활에 어떠한 영향을 미치는지 10 개의 항목으로 구성되어 있으며, 크게 두 가지 영역, 사회-심리 영역과 신체영역으로 되어 있다. 평가는 1-5점 체계 로서 ' $1=$ 문제가 전혀 없다, $2=$ 약간 문제가 있다, $3=$ 중간 정도 문 제가 있다, $4=$ 문제가 많다, $5=$ 문제가 더 이상 나쁠 수 없을 만큼 심각하다'이며, 원점수는 0-100점까지로 표준화할 수 있는데 0점은 삶의 질이 가장 나쁜 것을 의미하고, 100 점은 음성장애가 삶의 질 에 아무 영향을 미치지 않는 것으로 의미한다. 본 연구에서는
K-VFI와 동일하게 점수가 높을수록 문제 중증도가 높아지도록 원 점수를 사용하였다. 본 연구에서는 한국어판 음성과 관련된 삶의 질(K-VQOL)을 사용하였다(Kim et al., 2007).

\section{자료의 수집과 분석}

자료의 수집

연구자는 Google 온라인 설문지를 통해 2017년 10월 9일부터 11 월 8 일까지 언어재활관련 온라인 커뮤니티에 온라인 설문이 가능 한 링크를 배포하여 182 명이 설문에 응답하였고, 12 월 2 일 언어치 료인의 날 행사장에서 수기로 2 차 설문을 34 명 실시하여 총 216 명 에게 설문에 대한 응답을 받았다. 직업적 음성사용자의 분류에 있 어 음성사용량에 대한 기준은 없으나 주당 치료 회기가 1-20회기 미만인 경우(50명)는 직업적 음성사용자의 음성사용량에 관한 본 연구의 취지에 부합하지 않고 연구의 결과에 영향을 미칠 수 있음 을 고려하여 연구대상에서 제외하였다.

\section{자료의 분석}

자료의 통계처리는 Statistics Package for the Social Science (SPSS) version 21.0 을 이용하였으며 95\%수준에서 유의성을 검증하였다. 언어재활사의 근무기관에 따른 주당 치료 회기 수의 빈도에 따른 차이를 조사하기 위하여 카이제곱 검정을 실시하였으며, 치료 회기 빈도수, 주관적 음성장애 유무에 따른 K-VQOL-P (신체)-F (기능), K-VQOL-S (사회)-E (정서), K-VQOL-T (총점), K-VFI-F (피로), KVFI-P (신체), K-VFI-R (휴식), K-VFI-T (총점) 점수의 차이를 비교 하기 위하여 일원분산분석(one-way ANOVA)을 시행하였고, 집단 간 다중 비교를 위해 Scheffe로 사후분석을 실시하였다. 주관적 음 성장애 유무에 따른 K-VQOL, K-VFI 문항의 비교 분석은 독립표 본 $t$-test를 실시하였으며, $\mathrm{K}-\mathrm{VQOL}, \mathrm{K}-\mathrm{VFI}$, 주관적인 음성증상과 음성오남용의 관계를 알아보기 위해 Pearson 상관분석을 실시하 였다. K-VFI의 휴식문항('쉬고 난 뒤에는 목소리가 좋아진다', '쉬고 난 뒤에는 목소리를 낼 때 힘이 덜 든다', '쉬고 난 뒤에는 목소리의 거친 정도가 줄어든다')은 '말을 하면 목에 피로감이 느껴진다'와 같이 부정형으로 된 다른 문항과는 달리 긍정형 문장으로 이루어 져 역채점하여 분석을 실시하였다. 주관적인 음성증상은 연구자가 설문지에 제시한 14 가지 음성증상(바람 새는 소리, 쥐어짜는 소리, 약한 목소리, 쉰 목소리, 말할 때 목에 힘이 들어감, 말할 때 목소리 가 끊어짐, 말할 때 힘이 듦, 말할 때 목에 통증, 말할 때 목소리가 갈 라짐, 음성피로감 경험, 음도저하, 음도상승, 노래에서 고음발성 곤 란, 노래에서 저음발성 곤란) 중 대상자들이 현재 경험하고 있거나 경험했던 증상의 유무(유 $=1$ 점, 무 $=0$ 점)에 따라 각 개인의 증상을 
합하여 연속변수로 처리하여 분석하였다.

\section{연구결과}

\section{근무기관에 따른 주당 치료 회기 수의 빈도}

언어재활사의 근무기관에 따른 주당 치료 회기 수의 빈도와 백 분율은 Table 2와 같다. 집단별로 주당 치료 회기 수를 살펴보면, 사 설센터 집단은 20-29회기와 30-39회기가 29.2\% (40명), 40회기 이 상이 $7.3 \%$ (10명)로 나타났으며, 복지관 집단은 20-29회기가 7.3\% (10명), 30-39회기가 2.9\% (4명), 40 회기 이상이 .7\% (1명)로 나타났 다. 병원 집단은 20-29회기가 5.1\% (7명), 30-39회기가 4.4\% (6명), 40 회기 이상이 $10.9 \%$ (15명)로 나타났다. 주당 치료 회기 수를 살펴 보면 20-29회기를 치료하는 경우가 $43.8 \%, 30-39$ 회기가 $37.2 \%, 40$ 회기 이상 치료하는 경우가 $19 \%$ 였다. 40 회기 이상 치료하는 대상자 중 가장 높은 비율은 차지한 근무기관은 병원(10.9\%)이었으며, 통 계적으로 근무기관에 따른 주당 치료 회기 수의 빈도는 유의한 차 이가 있는 것으로 나타났다 $(p=.000)$.

Table 2. Sessions per week based on SLP's workplace

\begin{tabular}{lccccc}
\hline & \multicolumn{4}{c}{ Sessions per week } & \multirow{2}{*}{$\chi^{2}$} \\
\cline { 2 - 5 } & $20-29$ & $30-39$ & $40+$ & Total & \\
\hline Center & $40(29.2)$ & $40(29.2)$ & $10(7.3)$ & $90(65.7)$ & $31.243^{* * *}$ \\
Welfare center & $10(7.3)$ & $4(2.9)$ & $1(.7)$ & $15(10.9)$ & \\
Hospital & $7(5.1)$ & $6(4.4)$ & $15(10.9)$ & $28(20.4)$ \\
others & $3(2.2)$ & $1(.7)$ & $0(0)$ & $4(2.9)$ & \\
Total & $60(43.8)$ & $51(37.2)$ & $26(19)$ & $137(100)$ \\
\hline
\end{tabular}

Values are presented as number $(\%)$.

$\mathrm{SLP}=$ speech-language pathologist.

${ }^{* * *} p \leq .001$.

\section{근무기관 형태에 따른 음성과 관련된 삶의 질과 음성피로지수}

Table 3은 근무기관에 따른 음성과 관련된 삶의 질과 음성피로 도를 비교한 것이다. 음성과 관련된 삶의 질의 총점과 신체-기능 및 사회-정서면과 음성피로도 검사의 총점과 피로, 신체, 휴식면의 점 수는 유의한 차이가 없는 것으로 나타났다.

\section{주당 치료 회기 수에 따른 음성과 관련된 삶의 질과 음성피로지수}

주당 치료 회기 수에 따른 음성과 관련된 삶의 질 및 음성피로지 수 총점은 Table 4 와 같다. 음성과 관련된 삶의 질의 신체-기능면은 주당 20-29회기는 8.32점 $( \pm 3.85), 30-39$ 회기는 8.69점 $( \pm 4.28), 40$ 회기 이상은 9.08점 $( \pm 4.35)$ 이었으며, 사회-정서면은 20-29회기가 4.83점( \pm 2.10$), 30-39$ 회기가 5.45점( \pm 3.07$), 40$ 회기 이상이 5.62점 ( \pm 3.56$)$ 이었으며 총 점수는 20-29회기가 13.15점 $( \pm 5.83), 30$-39회

Table 4. Comparisons of K-VQOL and K-VFI based on sessions per week

\begin{tabular}{lcccr}
\hline & \multicolumn{3}{c}{ Sessions per week } & \\
\cline { 2 - 4 } & $20-29(\mathrm{~N}=60)$ & $30-39(\mathrm{~N}=51)$ & $40+(\mathrm{N}=26)$ & \\
\hline K-VQOL & & & & \\
$\quad$ Physical-functional & $8.32 \pm 3.85$ & $8.69 \pm 4.28$ & $9.08 \pm 4.35$ & .329 \\
Social-emotional & $4.83 \pm 2.10$ & $5.45 \pm 3.07$ & $5.62 \pm 3.56$ & 1.006 \\
Total & $13.15 \pm 5.83$ & $14.14 \pm 7.14$ & $14.69 \pm 7.62$ & .579 \\
K-VFI & & & & \\
Fatigue & $15.18 \pm 9.62$ & $17.63 \pm 11.44$ & $17.27 \pm 11.84$ & .795 \\
Physical & $5.58 \pm 5.42$ & $6.33 \pm 5.90$ & $6.92 \pm 6.00$ & .557 \\
Rest & $6.18 \pm 4.16$ & $5.33 \pm 3.87$ & $5.50 \pm 3.83$ & .682 \\
Total & $26.95 \pm 12.56$ & $29.29 \pm 14.43$ & $29.69 \pm 15.06$ & .554 \\
\hline
\end{tabular}

Values are presented as mean \pm SD.

$\mathrm{K}-\mathrm{V} Q \mathrm{OL}=$ Korean version of Voice-Related Quality of Life; K-VFI= Korean version of Vocal Fatigue Index.

Table 3. Comparisons of K-VQOL and K-VFI based on workplace

\begin{tabular}{lcccc}
\hline & Center $(\mathrm{N}=90)$ & Welfare center $(\mathrm{N}=15)$ & Hospital $(\mathrm{N}=28)$ & Others $(\mathrm{N}=4)$ \\
\hline K-V00L & & & & \\
Physical-functional & $8.47 \pm 4.04$ & $9.33 \pm 4.97$ & $8.46 \pm 4.08$ & $9.75 \pm 2.22$ \\
Social-emotional & $5.18 \pm 2.81$ & $5.40 \pm 3.14$ & $5.32 \pm 2.86$ & $4.50 \pm .58$ \\
Total & $13.64 \pm 6.64$ & $14.73 \pm 8.05$ & $13.79 \pm 6.66$ & $14.25 \pm 2.06$ \\
K-VFI & & & & .923 \\
Fatigue & $16.18 \pm 10.55$ & $17.00 \pm 11.01$ & $16.68 \pm 11.77$ & $20.25 \pm 9.64$ \\
Physical & $6.09 \pm 5.61$ & $6.87 \pm 5.50$ & $5.43 \pm 6.11$ & $8.75 \pm 6.65$ \\
Rest & $5.51 \pm 4.14$ & $5.40 \pm 3.36$ & $6.68 \pm 3.78$ & $5.50 \pm 4.36$ \\
Total & $27.78 \pm 13.65$ & $29.27 \pm 13.85$ & $28.79 \pm 14.46$ & $34.50 \pm 13.10$ \\
\hline
\end{tabular}

Values are presented as mean $\pm \mathrm{SD}$.

$\mathrm{K}-\mathrm{VQOL}=$ Korean version of Voice-Related Quality of Life; K-VFI= Korean version of Vocal Fatigue Index. 
기가 14.14 점 $( \pm 7.14), 40$ 회기 이상이 14.69점( \pm 7.62$)$ 이었다. 한국 판 음성피로도 검사에서 피로면은 20-29회기가 15.18점( \pm 9.62$)$, $30-39$ 회기가 17.63점 $( \pm 11.44), 40$ 회기 이상이 17.27점 $( \pm 11.84)$ 이 었으며, 신체면은 20-29회기가 5.58점( \pm 5.42$), 30-39$ 회기가 6.33점 ( \pm 5.90$), 40$ 회기 이상이 6.92점 $( \pm 6.00)$ 이었다. 휴식면에서는 20-29 회기가 6.18점( \pm 4.16$), 30-39$ 회기가 5.33점 $( \pm 3.87), 40$ 회기 이상이 5.50점 $( \pm 3.83)$ 이었으며, 총 점수는 20-29회기가 26.95점( \pm 12.56$)$, $30-39$ 회기가 29.29점( \pm 14.43$), 40$ 회기 이상이 29.69점( \pm 15.06$)$ 이 었다. 음성과 관련된 삶의 질의 총점과 신체-기능 및 사회정서면, 음 성피로도 검사의 신체면은 40회기 이상, 30-39회기, 20-29회기 순으 로 음성피로도 검사의 피로면은 30-39회기, 40회기 이상, 20-29회기 순으로 점수가 높았으나 통계적으로 유의한 차이가 나타나지 않아, 주당 치료 수에 따른 음성과 관련된 삶의 질과 음성피로도의 차이

Table 5. Comparisons of K-VQOL and K-VFI according to with and without Subjective chronic voice problems

\begin{tabular}{lccc}
\hline & VD $(N=50)$ & NVD $(N=87)$ & $t$ \\
\hline K-VOOL & & & \\
Physical-functional & $10.76 \pm 5.16$ & $7.36 \pm 2.64$ & $4.345^{* * *}$ \\
Social-emotional & $6.50 \pm 3.80$ & $4.47 \pm 1.63$ & $3.593^{* * *}$ \\
Total & $17.26 \pm 8.75$ & $11.83 \pm 3.99$ & $4.150^{* * *}$ \\
K-VFI & & & \\
Fatigue & $22.64 \pm 10.98$ & $12.95 \pm 8.90$ & $5.314^{* * *}$ \\
Physical & $10.38 \pm 5.90$ & $3.66 \pm 3.85$ & $7.213^{* * *}$ \\
Rest & $3.84 \pm 3.03$ & $6.82 \pm 4.06$ & $-4.885^{* * *}$ \\
Total & $36.86 \pm 14.76$ & $23.45 \pm 10.35$ & $5.670^{* * *}$ \\
\hline
\end{tabular}

Values are presented as mean \pm SD.

$\mathrm{K}-\mathrm{VOOL}=$ Korean version of Voice-Related Quality of Life; K-VFI= Korean version of Vocal Fatigue Index; SLP= speech-language pathologist; VD=SLPs with subjective chronic voice problems; NVD=SLPs without subjective chronic voice problems. ${ }^{* * *} p \leq .001$.
는 없는 것으로 나타났다.

\section{주관적 음성장애 유무에 따른 음성과 관련된 삶의 질과 음성피로도 비교}

Table 5는 주관적인 만성적 음성문제 유무에 음성과 관련된 삶 의 질의 총점과 신체-기능 및 사회정서면, 음성피로도 검사의 피로 면, 신체면 그리고 휴식면 점수를 비교한 것으로 음성피로도 검사 의 휴식문항은 다른 문항과는 달리 긍정형 문장으로 이루어져 역 채점한 후 분석하였다. 음성피로도의 휴식면을 제외한 모든 항목 에서 음성문제가 있는 집단이 음성문제가 없는 집단에 비해 통계 적으로 유의하게 더 높은 점수를 보인 반면 음성피로도의 휴식면 에서는 유의하게 더 낮은 점수를 보였다( $p \leq .001)$.

\section{근무경력에 따른 음성과 관련된 삶의 질과 음성피로도 비교}

Table 6은 대상자들의 경력에 따른 음성과 관련된 삶의 질의 총

Table 7. Correlations between vocal symptoms, voice abuse and misuse, KVQOL and K-VFI among Korean SLPS

\begin{tabular}{|c|c|c|c|c|c|}
\hline & & $\begin{array}{l}\text { K-VQOL } \\
\text { total }\end{array}$ & $\begin{array}{l}\text { K-VFI } \\
\text { total }\end{array}$ & $\begin{array}{l}\text { Voice abuse and } \\
\text { misuse total }\end{array}$ & $\begin{array}{c}\text { Vocal } \\
\text { symptoms }\end{array}$ \\
\hline \multirow[t]{2}{*}{ K-VOOL total } & $r$ & 1 & $.582^{* *}$ & $.417^{* *}$ & $.592^{* *}$ \\
\hline & $p$ & & .000 & .000 & .000 \\
\hline \multirow[t]{2}{*}{ K-VFI total } & $r$ & $.582^{* *}$ & 1 & $.353^{* *}$ & $.398^{* *}$ \\
\hline & $p$ & .000 & & .000 & .000 \\
\hline \multirow{2}{*}{$\begin{array}{l}\text { Voice abuse and } \\
\text { misuse total }\end{array}$} & $r$ & $.417^{* *}$ & $.353^{* *}$ & 1 & $.386^{* *}$ \\
\hline & $p$ & .000 & .000 & & .000 \\
\hline \multirow[t]{2}{*}{ Vocal symptoms } & $r$ & $.592^{* *}$ & $.398^{* *}$ & $.386^{* *}$ & 1 \\
\hline & $p$ & .000 & .000 & .000 & \\
\hline
\end{tabular}

$\mathrm{K}-\mathrm{V} Q \mathrm{OL}=$ Korean version of Voice-Related Quality of Life; K-VFI= Korean version of Vocal Fatigue Index; SLP=speech-language pathologist.

${ }^{* *} p \leq .01$.

Table 6. Comparisons of K-VQOL and K-VFI according to clinical career

\begin{tabular}{|c|c|c|c|c|c|}
\hline & \multicolumn{4}{|c|}{ Career (yr) } & \multirow{2}{*}{$F$} \\
\hline & $>1(N=15)$ & $1-4(N=43)$ & $4-7(N=53)$ & $>7(N=26)$ & \\
\hline \multicolumn{6}{|l|}{ K-VOOL } \\
\hline Physical-functional & $7.73 \pm 2.49$ & $9.06 \pm 4.89$ & $8.7 \pm 3.98$ & $8.11 \pm 3.64$ & .656 \\
\hline Social-emotional & $4.33 \pm .81$ & $5.44 \pm 3.09$ & $5.32 \pm 2.87$ & $5.11 \pm 2.90$ & .622 \\
\hline Total & $12.07 \pm 3.17$ & $14.51 \pm 7.69$ & $14.01 \pm 6.67$ & $13.23 \pm 6.45$ & .577 \\
\hline \multicolumn{6}{|l|}{ K-VFI } \\
\hline Fatigue & $9.93 \pm 7.96$ & $17.49 \pm 9.99$ & $17.47 \pm 11.72$ & $16.61 \pm 10.45$ & .092 \\
\hline Physical & $2.53 \pm 3.22$ & $6.83 \pm 5.61$ & $6.70 \pm 6.26$ & $5.80 \pm 5.17$ & .063 \\
\hline Rest & $7.06 \pm 4.92$ & $6.48 \pm 3.97$ & $6.56 \pm 3.73$ & $6.19 \pm 3.96$ & .926 \\
\hline Total & $19.53 \pm 12.22$ & $30.81 \pm 17.41$ & $30.73 \pm 18.95$ & $28.61 \pm 16.53$ & .148 \\
\hline
\end{tabular}

Values are presented as mean $\pm S D$.

$\mathrm{K}$-VOOL= Korean version of Voice-Related Quality of Life; K-VFI= Korean version of Vocal Fatigue Index. 
점과 신체-기능 및 사회정서면, 음성피로도 검사의 피로면, 신체면 그리고 휴식면 점수의 차이를 비교한 것이다. 음성피로도 검사의 휴식문항은 다른 문항과는 달리 긍정형 문장으로 이루어져 역채점 한 후 분석하였다. 그 결과, 따른 음성과 관련된 삶의 질이나 음성피 로지수에서 7년 이상 집단이 1년 미만 집단보다는 점수가 높고 1-4 년 미만과 4-7년 미만 집단보다는 낮은 경향을 보였으나 통계적으
로 유의한차이는 없었다.

\section{주관적 음성증상, 음성오남용, 음성피로지수 및 음성과 관련된 삶의 질의 상관}

Table 7에 나타난 바와 같이 주관적인 음성증상, 음성오남용, 음 성과 관련된 삶의 질 검사와 음성피로도 검사 간의 상관성을 알아

Table 8. Analysis of K-VQOL items between with vs. without subjective chronic voice problems in Korean SLPS

\begin{tabular}{|c|c|c|c|c|}
\hline Item & $V P(N=50)$ & $\mathrm{NVP}(\mathrm{N}=87)$ & $t$ & $p$-value \\
\hline I have trouble speaking loudly or being heard in noisy situations. & $1.80 \pm 1.01$ & $1.31 \pm .75$ & 2.985 & $.004^{* *}$ \\
\hline I run out of air and need to take frequent breaths when talking. & $1.84 \pm 1.03$ & $1.44 \pm .72$ & 2.588 & $.011^{*}$ \\
\hline I sometimes do not know what will come out when I begin speaking. & $1.96 \pm 1.26$ & $1.20 \pm .59$ & 3.977 & $.000^{* * *}$ \\
\hline I am sometimes anxious or frustrated (because of my voice). & $1.84 \pm 1.18$ & $1.20 \pm .66$ & 3.476 & $.001^{* * *}$ \\
\hline I sometimes get depressed (because of my voice). & $1.82 \pm 1.25$ & $1.13 \pm .59$ & 3.613 & $.001^{* * *}$ \\
\hline I have trouble using the telephone (because of my voice). & $1.78 \pm 1.11$ & $1.11 \pm .44$ & 4.049 & $.000^{* * *}$ \\
\hline I have trouble doing my job or practicing my profession (because of my voice). & $1.98 \pm 1.03$ & $1.09 \pm .036$ & 5.839 & $.000^{* * *}$ \\
\hline I avoid going out socially (because of my voice). & $1.46 \pm .93$ & $1.05 \pm .31$ & 2.961 & $.004^{* *}$ \\
\hline I have to repeat myself to be understood. & $1.40 \pm .90$ & $1.18 \pm 5.39$ & 1.514 & .128 \\
\hline I have become less outgoing (because of my voice). & $1.38 \pm .90$ & $1.06 \pm .29$ & 2.368 & $.021^{*}$ \\
\hline
\end{tabular}

Values are presented as mean $\pm \mathrm{SD}$.

K-VQOL= Korean version of Voice-Related Quality of Life; SLP= speech-language pathologist; VD=SLPs with subjective chronic voice problems; NVD=SLPS without subjective chronic voice problems.

${ }^{*} p \leq .05,{ }^{* *} p \leq .01,{ }^{* * *} p \leq .001$.

Table 9. Analysis of K-VFl items between with vs. without subjective chronic voice problems in Korean SLPS

\begin{tabular}{|c|c|c|c|c|}
\hline Item & $V P(N=50)$ & $\operatorname{NVP}(\mathrm{N}=87)$ & $t$ & $p$-value \\
\hline I don't feel like talking after a period of voice use. & $2.24 \pm 1.30$ & $1.56 \pm 1.25$ & 2.967 & $.004^{* *}$ \\
\hline My voice feels tired when I talk more. & $2.76 \pm 1.10$ & $2.07 \pm 1.08$ & 3.571 & $.001^{* *}$ \\
\hline I experience increased sense of effort with talking. & $2.16 \pm 1.31$ & $1.09 \pm 1.14$ & 4.803 & $.000^{* * *}$ \\
\hline My voice gets hoarse with voice use. & $2.14 \pm 1.32$ & $1.01 \pm 1.19$ & 4.983 & $.000^{* * *}$ \\
\hline It feels like work to use my voice. & $2.28 \pm 1.29$ & $1.52 \pm 1.35$ & 3.273 & $.001^{* *}$ \\
\hline I tend to generally limit my talking after a period of voice use. & $2.24 \pm 1.32$ & $1.53 \pm 1.23$ & 3.117 & $.002^{* *}$ \\
\hline I avoid social situations when I know I have to talk more. & $1.50 \pm 1.27$ & $.70 \pm 1.02$ & 3.804 & $.000^{* * *}$ \\
\hline I feel I cannot talk to my family after a work day. & $1.74 \pm 1.44$ & $.83 \pm 1.06$ & 4.245 & $.000^{* * *}$ \\
\hline It is effortful to produce my voice after a period of voice use. & $1.82 \pm 1.34$ & $.91 \pm 1.12$ & 4.745 & $.000^{* * *}$ \\
\hline I find it difficult to project my voice with voice use. & $1.32 \pm 1.39$ & $.63 \pm .93$ & 3.463 & $.003^{* *}$ \\
\hline My voice feels weak after a period of voice use. & $2.34 \pm 1.33$ & $1.10 \pm 1.14$ & 5.498 & $.000^{* * *}$ \\
\hline I experience pain in the neck at the end of the day with voice use. & $2.18 \pm 1.26$ & $.77 \pm .96$ & 7.372 & $.000^{* * *}$ \\
\hline I experience throat pain at the end of the day with voice use. & $2.16 \pm 1.25$ & $.85 \pm 1.03$ & 6.619 & $.000^{* * *}$ \\
\hline My voice feels sore when I talk more. & $2.20 \pm 1.40$ & $1.10 \pm 1.11$ & 5.050 & $.000^{* * *}$ \\
\hline My throat aches with voice use. & $2.06 \pm 1.32$ & $.68 \pm .95$ & 7.112 & $.000^{* * *}$ \\
\hline I experience discomfort in my neck with voice use. & $1.78 \pm 1.33$ & $.60 \pm .90$ & 6.207 & $.000^{* * *}$ \\
\hline My voice feels better after I have rested. & $2.72 \pm 1.07$ & $1.95 \pm 1.36$ & 3.641 & $.001^{* *}$ \\
\hline The effort to produce my voice decreases with rest. & $2.70 \pm 1.07$ & $1.92 \pm 1.43$ & 3.348 & $.000^{* * *}$ \\
\hline The hoarseness of my voice gets better with rest. & $2.74 \pm 1.03$ & $1.71 \pm 1.47$ & 4.365 & $.000^{* * *}$ \\
\hline
\end{tabular}

Values are presented as mean $\pm S D$.

$\mathrm{K}-\mathrm{VFI}=$ Korean version of Vocal Fatigue Index; SLP= speech-language pathologist; VD=SLPs with subjective chronic voice problems; NVD=SLPS without subjective chronic voice problems.

${ }^{* *} p \leq .01,{ }^{* * *} p \leq .001$. 
보기 위해 Pearson 적률상관분석을 실시한 결과, 음성과 관련된 삶 의 질 총점과 음성피로 총점 간에 중간 정도의 유의한 정적 상관관 계를 보였으며 $(r=.582)$, 음성오남용 정도 $(r=.417)$ 와 주관적인 음 성증상 $(r=.592)$ 과도 유의한 정적 상관성을 나타내었다. 음성피로 총점은 음성오남용 정도 $(r=.353)$ 와주관적인 음성증상 $(r=.398)$ 과 중간 정도의 유의한 정적 상관관계를 보였으며, 음성오남용 정도는 주관적 음성증상 $(r=.386)$ 과 중간 정도의 유의한 정적 상관관계를 보였다.

\section{언어재활사의 주관적 음성문제 유무에 따른 음성과 관련된 삶의 질 문항분석}

Table 8은 주관적 음성문제 유무에 따른 음성과 관련된 삶의 질 검사의 문항별 점수를 비교한 것이다. 주관적인 만성적 음성문제가 있는 집단은 음성문제가 없는 집단에 비해 '남들이 이해할 수 있도 록 반복해서 말을 해야만 한다'는 문항을 제외한 모든 문항에서 유 의하게 점수가 더 높았다.

\section{언어재활사의 주관적 음성문제 유무에 따른 음성피로지수 문항분석}

Table 9는 주관적 음성문제 유무에 따른 음성피로도 검사의 문 항별 점수를 비교한 것이다. 주관적인 만성적 음성문제가 있는 집 단은 음성문제가 없는 집단에 비해 모든 항목에서 유의하게 점수 가 더 높았다.

\section{논의 및 결론}

본 연구는 한국언어재활사의 직업적 음성사용실태를 파악하고, 언어재활사의 음성건강 증진 향상 방안을 모색하기 위해 언어재활 사의 근무기관 유형, 주당 치료 회기 수, 경력, 주관적인 음성문제여 부에 따른 음성피로도 검사와 음성과 관련된 삶의 질 검사의 점수 를 비교하였다. 총 137 명 응답자 중 50명(36.5\%)이 주관적으로 만성 적인 음성문제가 있는 것으로 보고하였으며, 이는 응답자의 $1 / 3$ 이 상이 만성적인 음성장애를 경험한다는 것을 의미한다. 또한, 언어 재활사의 근무기관 유형, 주당 치료 회기 수, 경력에 따른 음성피로 나 음성과 관련된 삶의 질은 차이가 없었으며, 주관적인 음성문제 여부에 따라 유의한 차이를 보였다. 즉, 음성문제가 있는 집단이 음 성문제가 없는 집단에 비해 음성과 관련된 삶의 질이 저하되고 음 성피로도가 더 높은 것으로 나타났다. 한편, 주관적인 음성문제 유 무에 따라 K-VFI의 각 문항을 비교한 결과, 19 개 문항 모두에서 유 의한 차이를 보였다. 즉, 주관적인 음성문제를 경험하는 경우, 음성
피로와 신체적 불편감이 더 크고, 음성휴식 후에도 음성 회복에 어 려움이 있는 것으로 나타났다. 음성과 관련된 삶의 질 총점은 음성 피로 총점 $(r=.582)$, 음성오남용 정도 $(r=.417)$ 및 주관적인 음성증 상 $(r=.592)$ 과 중간 정도의 유의한 정적 상관성을 나타내었다. 음성 피로 총점은 음성오남용 정도 $(r=.353)$ 와 주관적인 음성증상 $(r=$ .398)과 중간정도의 유의한 정적 상관관계를 보였으며, 음성오남용 정도는 주관적 음성증상 $(r=.386)$ 과 중간 정도의 유의한 정적 상관 관계를 보였다.

주관적인 음성문제 유무에 따라 $\mathrm{K}-\mathrm{VQOL}$ 의 문항분석을 실시 한 결과, '남들이 이해할 수 있도록 반복해서 말을 해야만 한다’를 제외한 9개 문항에서 두 집단 간 유의한 차이가 있었다. 따라서, 직 업적 음성사용에서 비롯되는 언어재활사의 음성문제가 언어재활 사 개인의 직업활동과 의사소통 방해와 같은 신체-기능적 측면과 사회적 활동의 제한, 우울감과 불안감 같은 사회-정서적 측면의 어 려움으로 이어져 음성과 관련된 삶의 질을 저하시킬 수 있음을 시 사하였다.

Kim과 Choi (2018)의 연구의 결과에 의하면, 주관적인 음성문제 가 있는 언어재활사 집단은 없는 언어재활사 집단에 비해 음성오남 용과 주관적인 음성증상이 더 많았는데, 본 연구에서 음성피로나 음성과 관련된 삶의 질에 영향을 미치는 요인은 주당 치료 회기 수 나 근무기관 유형과 같은 직업과 관련된 환경적 혹은 외적 요인보 다는 언어재활사 개인의 발성습관이나 발성패턴과 같은 개개인의 음성사용과 관련된 내적인 요인에 의해 영향을 받을 수 있음을 시 사하였다. Welham과 Maclagan (2003)은 음성피로와 관련한 문헌 고찰에서 최소한 2 시간 이상의 지속적인 발성 후 음성이 부정적으 로 변한다고 하였다. 따라서, 치료가 집중되고 연속되는 지속적인 음성사용시간 역시 음성피로와 음성과 관련된 삶의 질에 중요한 요소가 되므로, 추후에는 음성피로도를 조사하는 데 있어서 하루 의 지속적인 음성사용량 및 회기 간 휴식 시간을 조사하는 것이 필 요하다. 본 연구에서는 총 회기 수만을 측정하였으나, 지속적인 음 성사용량이 음성피로에 더 영향을 미칠 수 있으므로 추후의 연구 에서는 이러한 근무 환경 요인을 좀 더 세심히 살펴볼 필요가 있다.

근무기관 유형에 따른 주당 치료 회기 수는 20-29회기를 치료하 는 경우가 $43.8 \%, 30-39$ 회기가 $37.2 \%, 40$ 회기 이상 치료하는 경우 가 $19 \%$ 이었으며, 40 회기 이상 치료하는 대상자 중 가장 높은 비율 은 차지한 근무기관은 병원(10.9\%)이었다. 근무기관 유형에 따라 통 계적으로 주당 치료 회기 수에 유의한 차이가 있었지만, 정규직이 나 계약직 같은 고용형태나 월급제나 비율제와 같은 급여조건, 재 활병원과 대학병원 혹은 재활의학과나 이비인후과와 같은 근무기 관이나 치료 대상자의 유형 등 다양한 변수들이 존재하기 때문에 
결과 해석에 한계가 따를 것으로 사료된다.

본 연구의 결과를 종합하면, 직업적 음성사용으로 인한 음성피 로와 음성과 관련된 삶의 질 증진을 위해서는 주관적 음성문제에 영향을 미치는 음성오남용을 줄일 뿐 아니라 음성오남용에서 비롯 되는 신체적 문제를 개선시킬 수 있는 적극적인 자가 음성관리프 로그램의 적용이 필요하다고 할 수 있겠다.

Wilson, Deary, Millar와 Mackenzie (2002)는 SF-36을 통해 후 두 내시경상 성대에 이상 소견은 없으나 음성문제가 2달 이상 지속 되는 환자군이 음성문제가 없는 대조군에 비해 건강과 관련된 전 반적인 삶의 질이 떨어진다고 보고하였다. Krischke 등(2005)도 기 능적 및 기질적 음성장애 집단이 비음성장애 집단에 비해 신체적 기능 $(\mathrm{PF})$ 과 정신건강 $(\mathrm{MH})$ 을 제외한 영역에서 점수가 더 높은 것 으로 보고하였다. 본 연구에서는 직업적 음성사용자로서 언어재활 사의 음성피로도, 음성과 관련된 삶의 질을 살펴보았는데, 추후 연 구에서는 음성뿐만 아니라 전반적인 건강과 관련된 언어재활사의 삶의 질에 대한 연구로 확대할 필요가 있다.

Hunter와 Banks (2017)에서 여성 교사가 남성교사에 비해 음성 피로도 검사의 피로감 영역과 신체적 불편함 영역에서 높은 점수 를 보이며 음성피로와 신체적 불편함이 더 큰 것으로 나타났다. Van Houtte, Claeys, Wuyts와 Van Lierde (2011)는 여성이 남성에 비해 성대길이가 더 짧지만 더 높은 주파수를 산출해야 하고, 크기 가 작은 만큼 표층의 회복에 필요한 히알루론산 역시 적기 때문에 성대를 보호하거나 회복을 위한 생물학적 방어기전이 남성에 비해 취약할 수 있다고 보고하였는데, 현재까지 우리나라에서 여성 언어 재활사의 비중이 높은 점을 감안할 때 여성 SLP들이 음성오남용에 의한 음성문제가 발생할 위험이 높다고 할 수 있겠다. 그러므로 음 성오남용 제거를 위한 음성위생 실천 이외에 좀 더 적극적인 음성 관리가 요구된다.

본 연구는 다수의 한국 언어재활사를 대상으로 현재 직업과 관 련된 음성 피로와삶의 질 및 음성문제에 영향을 줄 수 있는 다양한 요인에 대해 조사하였다는 것에 의의가 있다. 추후의 연구에서는 언 어재활사 개개인의 음성오남용을 발견하고 이에 따른 개인 맞춤형 음성위생 및 적극적인 음성건강 관리 및 교육을 위한 프로그램의 개발과 유용성에 대한 검증이 필요하겠다. 이러한 언어재활사의 음 성에 관한 연구는 언어재활사의 음성건강 증진뿐만 아니라 전반적 인 삶의 행복감과 직업에 대한 만족도를 향상시킬 수 있을 것이다.

\section{REFERENCES}

Cho, J. K. (2016). Acoustic characteristics and vocal fatigue associated with professional voice use of female telemarketers (Master's thesis). Daegu Catholic University, Gyeongsan, Korea

Choi, S. H., \& Choi, C. H. (2013). The characteristics of voice handicap index and vocal misuse and overuse in female elementary teachers. Phonetics and Speech Sciences, 5, 53-61.

Gelfer, M. P., Andrews, M. L., \& Schmidt, C. P. (1991). Effects of prolonged loud reading on selected measures of vocal function in trained and untrained singers. Journal of Voice, 5, 158-167.

Hogikyan, N. D., \& Sethuraman, G. (1999). Validation of an instrument to measure voice-related quality of life (V-RQOL). Journal of Voice, 13, 557569.

Hunter, E. J., \& Banks, R. E. (2017). Gender differences in the reporting of vocal fatigue in teachers as quantified by the Vocal Fatigue Index. Annals of Otology, Rhinology \& Laryngology, 126, 813-818.

Hunter, E. J., \& Titze, I. R. (2009). Quantifying vocal fatigue recovery: dynamic vocal recovery trajectories after a vocal loading exercise. Annals of Otology, Rhinology \& Laryngology, 118, 449-460.

Kang, Y., Chang, J. W., \& Koo, B. S. (2017). Relationship between voice fatigue and voice assessment in patients with voice disorders and applicability of Voice Fatigue Index in Korean version. Korean Journal of Otorhinolaryngology-Head and Neck Surgery, 60, 232-242.

Kim, J. O., Lim, S. E., Park, S. Y., Choi, S. H., Choi, J. N., \& Choi, H. S. (2007). Validity and reliability of Korean-version of Voice Handicap Index and voice-related quality of life. Phonetics and Speech Sciences, 14, 111-125.

Kim, J. S., \& Choi, S. H. (2018). Voice problems and self-care practice for vocal health: current status of Korean speech-language pathologists. Communication Sciences \& Disorders, 23, 414-424.

Kostyk, B. E., \& Rochet, A. P. (1998). Laryngeal airway resistance in teachers with vocal fatigue: a preliminary study. Journal of Voice, 12, 287-299.

Koufman, J. A., \& Isaacson, G. (1991). The spectrum of vocal dysfunction. Otolaryngologic Clinics of North America, 24, 985-988.

Krischke, S., Weigelt, S., Hoppe, U., Köllner, V., Klotz, M., Eysholdt, U., \& Rosanowski, F. (2005). Quality of life in dysphonic patients. Journal of Voice, $19,132-137$

Nanjundeswaran, C., Jacobson, B. H., Gartner-Schmidt, J., \& Abbott, K. V. (2015). Vocal Fatigue Index (VFI): development and validation. Journal of Voice, 29, 433-440.

Sataloff, R. T., Hawkshaw, M., \& Rosen, D. C. (1997). Medications: effects and side effects in professional voice users. In R. T. Sataloff (Ed.), Professional voice: the science and art of clinical care (pp. 457-470). San Diego, 
CA: Singular Publishing Group.

Scherer, R. C., Titze, I. R., Raphael, B. N., Wood, R. P., Ramig, L. A., \& Blager,

R. F. (1987). Vocal fatigue in a trained and an untrained voice user. In T. Baer et al. (Eds.) Laryngeal Function in Phonation and Respiration (pp. 533-

544). Boston, MA: College-Hill Press.

Solomon, N. P. (2008). Vocal fatigue and its relation to vocal hyperfunction. International Journal of Speech-Language Pathology, 10, 254-266.

Song, Y. K., \& Pyo, H. Y. (2010). A preliminary study on voice symptoms and Korean Voice Handicap Index of speech language pathologists. Phonetics and Speech Sciences, 2, 123-133.

Van Houtte, E., Claeys, S., Wuyts, F., \& Van Lierde, K. (2011). The impact of voice disorders among teachers: vocal complaints, treatment-seeking be- havior, knowledge of vocal care, and voice-related absenteeism. Journal of Voice, 25, 570-575.

Verdolini, K., Rosen, C. A., \& Branski, R. C. (2006). Classification manual for voice disorders-I. London: Routledge.

Vilkman, E. (2004). Occupational safety and health aspects of voice and speech professions. Folia Phoniatrica et Logopaedica, 56, 220-253.

Welham, N. V., \& Maclagan, M. A. (2003). Vocal fatigue: current knowledge and future directions. Journal of Voice, 17, 21-30.

Wilson, J. A., Deary, I. J., Millar, A., \& Mackenzie, K. (2002). The quality of life impact of dysphonia. Clinical Otolaryngology \& Allied Sciences, 27, 179182. 
Appendix 1. 언어재활사의 음성건강에 관한 설문

\section{[ 언어재활사의 음성건강에 관한 설문 ]}

\section{설문 1 기본정보}

1. 선생님의 성별은 어떻게 되십니까?
(1) 남
(2) 여

2. 선생님의 연령은 어떻게 되십니까?
(1) 20 대
(2) 30 대
(3) 40 대 이상

3. 선생님께서는 언어재활사로 일하신 지 얼마나 되셨습니까?
(1) 1년 미만
(2) 1년 이상 4년 미만
(3) 4년 이상 7년 미만
(4) 7년 이상

4. 선생님께서는 현재 일주일에 평균 몇 회기를 치료하십니까?
(1) 20회기 미만
(2) 20-29회기
(3) 30-39회기
(4) 40 회기 이상

5. 선생님께서 현재 근무하시는 기관은?
(1) 센터
(2) 복지관
(3) 병원
(4) 학교/교육청
(5) 기타

6. 선생님의 최종학력은?
(1) 전문학사 졸업
(2) 학사 졸업
(3) 비전공학부 후 석사 졸업
(4) 학부전공 후 석사 수료/졸업
(5) 박사 재학/수료/졸업

7. 선생님께서는 소화기계나 내분비계, 신경계 질환 혹은 정신과적 질환, 청력장애, 알러지성 질환을 않고 계십니까?
(1) 예
(2) 아니오

8. 선생님께서는 경구용 피임약, 갑상샘 질환, 호르몬 계통의 약물 및 알러지와 관련된 항 히스타민제와 같은 약물을 복용하십니까?
(1) 예
(2) 아니오

\section{설문 2 음성문제와 관련된 경험}

1. 선생님께서는 스스로 생각하시기에 음성사용의 불편함을 포함해 만성적인 음성문제를 가지고 계십니까?
(1) 예
(2) 아니오

2. 선생님 음성에 문제가 있다면 그 원인이 어디에 있다고 생각하십니까?
(1) 음성오남용
(2) 음성사용 습관
(3) 자발적인 음성관리 부족
(4) 건강문제
(5) 기타

3. 선생님께서는 음성문제로 언어재활을 쉬었던 경험(휴식)이 있습니까?
(1) 예
(2) 아니오
(3) 치료세션 감소
(4) 아니오, 그러나 쉴 필요를 느꼈다
(5) 기타

4. 다음 중에서 언어재활사로 일하시면서 경험했거나 현재 나타나고 있는 증상이 있다면 체크해 주십시오(중복선택 가능)
$\square$ 바람 새는 소리
$\square$ 말할 때 목에 힘이 들어감 $\quad \square$ 음도상승
$\square$ 말할 때 목소리가 갈라짐
$\square$ 음성피로감 경험
$\square$ 말할 때 목에 통증
$\square$ 음도저하
$\square$ 쥐어짜는 소리
$\square$ 약한 목소리
$\square$ 쉰 목소리
$\square$ 노래에서 고음 발성 곤란
$\square$ 노래에서 저음발성 곤란
$\square$ 말할 때 목소리가 끈어짐
$\square$ 말할 때 힘이 듦
$\square$ 기타

5. 선생님께서는 음성문제로 이비인후과 진료를 받으신 적이 있습니까?
(1) 예
(2) 아니오

6. 받으셨다면 어떤 치료를 받으셨습니까? (중복선택 가능)

$\square$ 음성휴식(침묵요법; 말하지 마세요.) $\square$ 음성위생교육 및 음성위생 지속 $\square$ 후두 미세술

$\square$ 약물치료

$\square$ 음성치료 
Ji Sung Kim, et al. • Vocal Fatigue of Speech Language Pathologists

Appendix 1. Continued

\section{설문 3 음성위생과 오남용}

1. 선생님께서는 음성위생에 대해 알고 계십니까?
(1) 예
(2) 아니오

2. 선생님께서는 음성위생을 수행하십니까?
(1) 아주 잘 수행한다
(2) 잘 수행한다
(3) 보통 수행한다
(4) 거의 수행하지 않는다
(5) 전혀 수행하지 않는다

3. 선생님께서는 자신의 음성사용이나 오남용을 평가해 보신 경험이 있으십니까?
(1) 예
(2) 아니오

4. 선생님께서는 매일 자신의 음성사용을 평가하거나 음성오남용 여부를 확인하십니까?
(1) 예
(2) 아니오

Appendix 2. 음성오남용 체크 리스트

[음성오남용 체크 리스트]

\begin{tabular}{|c|c|c|c|c|}
\hline 문 항 & $0=$ 안함 & 1=가끔 & 2=보통 & 3=자주 \\
\hline 소리 지르기 & & & & \\
\hline 큰 소리로 말하기 & & & & \\
\hline 오랜 시간동안 말하기 & & & & \\
\hline 시끄러운 환경에서 말하기 & & & & \\
\hline 과도한 말하기나 이야기 하기 & & & & \\
\hline 먼지 나는 곳에서 말하기 & & & & \\
\hline 속삭이기 & & & & \\
\hline 지나치게 크게 울거나 웃기 & & & & \\
\hline 노래 부르기 & & & & \\
\hline 자신의 음역보다 지나치게 낮거나 높은 & & & & \\
\hline 흡연 & & & & \\
\hline 알코올섭취 & & & & \\
\hline 카페인 섭취(커피, 녹차, 탄산음료 등) & & & & \\
\hline 기침이나 목청 가다듬기 & & & & \\
\hline
\end{tabular}


Appendix 3. Korean-Version of Voice-Related Quality of Life (K-VQOL)

\section{[ Korean-Version of Voice-Related Quality of Life (K-VQOL) ]}

당신의 목소리 문제가 당신의 일상생활에 어떻게 영향을 미치는지를 알고자 합니다. 본 설문지에서 목소리와 관련되어 발생 가능한 문제들을 찾고자 합니다. 지난 2주 동안 목소리가 어떤지를 고려해서 각 문항에 응답해 주시기 바랍니다. 옳고 틀린 정답은 없습니다.

목소리 문제가 생겼을 때의 심각한 정도와 얼마나 자주 목소리 문제가 생기는지를 고려하여 각 항목에 얼마나 "나쁜지(당신이 가지고 있는 문제의 정도가)"를 체크해 주시기 바랍니다. 다음의 평가척도를 참고로 하여 체크해 주시기 바랍니다.

$1=$ 문제가 전혀 없다. $2=$ 약간 문제가 있다. $3=$ 중간 정도 문제가 있다. $4=$ 문제가 많다. $5=$ 문제가 더 이상 나쁠 수 없을 만큼 심각하다.

1. 내 목소리 때문에 시끄러운 상황에서 크게 말하기가 힘들거나 남들이 내 말을 잘 알아듣기 힘들어 한다. $\quad \begin{array}{lllll}1 & 2 & 3 & 4 & 5\end{array}$

2. 말할 때 숨이 차고 숨을 자주 쉰다.

3. 때때로 말을 시작할 때 어떤 소리가 나올지 예측하기 힘들다.

4. (내 목소리 때문에) 때때로 불안하거나 당황스럽다.

5. (내 목소리 때문에) 때때로 우울해진다.

6. (내 목소리 때문에) 전화 통화하는데 어려움이 있다.

7. (내 목소리 때문에) 직업이나 전문적인 일을 하는 동안 어려움이 있다.

8. (내 목소리 때문에) 외부로 나가 사회 생활하는 것을 피하게 된다.

9. 남들이 이해할 수 있도록 반복해서 말을 해야만 한다.

10. 내 목소리 때문에 덜 외향적이다.

$\begin{array}{lllll}1 & 2 & 3 & 4 & 5 \\ 1 & 2 & 3 & 4 & 5 \\ 1 & 2 & 3 & 4 & 5 \\ 1 & 2 & 3 & 4 & 5 \\ 1 & 2 & 3 & 4 & 5 \\ 1 & 2 & 3 & 4 & 5 \\ 1 & 2 & 3 & 4 & 5 \\ 1 & 2 & 3 & 4 & 5 \\ 1 & 2 & 3 & 4 & 5\end{array}$

Appendix 4. 음성피로도 검사(Vocal Fatigue Index)

\section{[ 음성피로도 검사 (Vocal Fatigue Index)]}

아래 표에는 일반적으로 음성문제와 관련되는 몇 가지 증상들이 나열되어 있습니다. 해당 증상들을 얼마나 자주 경험하는지 0점부터 4점까지 해당되는 점수 에 표시해 주십시오.

$0=$ 전혀 아니다. $1=$ 거의 아니다. $2=$ 때때로 그렇다. $3=$ 거의 그렇다. $4=$ 항상 그렇다.

Part I

1. 일정시간 동안 목소리를 쓰고 난 후에는 말하고 싶은 기분이 들지 않는다.

2. 말을 많이 하면 목소리에 피로감이 느껴진다.

3. 말을 할 때 점점 더 힘겨워지는 것이 느껴진다.

4. 목소리를 쓸수록 점점 더 쉰 소리가 난다.

5. 말하는 것이 일처럼 느껴진다.

6. 나는 일정시간 동안 목소리를 쓰고 난 후에 말을 더 이상 하지 않는 경향이 있다.

7. 말을 많이 해야 하는 자리나 상황을 피한다.

8. 퇴근 후에 가족과 이야기하는 것이 힘겹게 느껴진다.

9. 일정시간 동안 목소리를 쓰고 난 후에는 목소리를 내기가 힘이 든다.

10. 멀리서도 들릴 만 한 목소리를 내는 것이 힘이 든다.

11 일정시간 동안 목소리를 쓰고 난 후에는 목소리가 약해졌다고 느낀다.

$\begin{array}{lllll}0 & 1 & 2 & 3 & 4 \\ 0 & 1 & 2 & 3 & 4 \\ 0 & 1 & 2 & 3 & 4 \\ 0 & 1 & 2 & 3 & 4 \\ 0 & 1 & 2 & 3 & 4 \\ 0 & 1 & 2 & 3 & 4 \\ 0 & 1 & 2 & 3 & 4 \\ 0 & 1 & 2 & 3 & 4 \\ 0 & 1 & 2 & 3 & 4 \\ 0 & 1 & 2 & 3 & 4 \\ 0 & 1 & 2 & 3 & 4\end{array}$

\section{Part II}

12. 목소리를 사용한 날이면, 하루가 끝날 때쯤에 목 전체에 통증을 느낀다.

13. 목소리를 사용한 날이면, 하루가 끝날 때쯤에 목 안쪽에 통증을 느낀다.

14. 말을 많이 하면 목이 부은 느낌이 든다.

15. 목소리를 사용할 때 목 안쪽이 아프다.

16. 목소리를 사용할 때 목 전체가 불편함을 느낀다.

$\begin{array}{lllll}0 & 1 & 2 & 3 & 4 \\ 0 & 1 & 2 & 3 & 4 \\ 0 & 1 & 2 & 3 & 4 \\ 0 & 1 & 2 & 3 & 4 \\ 0 & 1 & 2 & 3 & 4\end{array}$

\section{Part III}

17. 쉬고 난 뒤에는 목소리가 좋아진다.

18. 쉬고 난 뒤에는 목소리를 낼 때 힘이 덜 든다.

19. 쉬고 난 뒤에는 목소리의 거친 정도가 줄어든다.

$\begin{array}{lllll}0 & 1 & 2 & 3 & 4 \\ 0 & 1 & 2 & 3 & 4 \\ 0 & 1 & 2 & 3 & 4\end{array}$




\section{국문초록}

\section{한국 언어재활사의 음성피로 및 음성과 관련된 삶의 질}

김지성 ${ }^{1,2}\left(\right.$ 학생, 언어재활사, 제 1 저자) $\cdot$ 최성희 ${ }^{1,3}$ (교수, 교신저자)

${ }^{1}$ 대구가톨릭대학교 대학원, ${ }^{2}$ 충북대학교병원 이비인후과, ${ }^{3}$ 대구가톨릭대학교 언어청각치료학과

배경 및 목적: 한국 언어재활사의 직업적 음성사용실태를 파악하고, 음성건강 증진 방안을 모색하기 위해 언어재활사의 음성피로도 검사와 음성과 관련된 삶의 질 검사의 점수를 비교하였다. 방법: 주당 20 회기 이상 치료하는 언어재활사 137 명(남 20 명, 여 117 명)에게 온라인이나 오프라인으로 음성과 관련된 설문과 K-VFI, K-VQOL을 실시하고 그 내용을 분석하였다. 연구에 참여한 언어재활사의 연 령은 20 대가 79 명, 30 대가 46 명, 40 대 이상이 12 명이었다. 결과: 언어재활사의 근무기관 유형, 주당 치료 회기 수, 경력, 주관적인 음성문 제 여부에 따른 음성피로도 검사(K-VFI)와음성과 관련된 삶의 질 검사(K-VQOL)의 점수를 비교한 결과 주관적인 음성문제가 있는 집 단은 주관적인 문제가 없는 집단에 비해 K-VQOL-P (신체)-F (기능), K-VQOL-S (사회)-E (정서), K-VQOL-T (총점), K-VFI-F (피로), KVFI-P (신체), K-VFI-R (휴식), K-VFI-T (총점)의 점수가 유의하게 더 높았다( $p \leq .001)$. 또한, 주관적 음성증상, 음성오남용, 음성피로지 수 및 음성과 관련된 삶의 질 간의 유의한 상관 $(p \leq .001)$ 이 나타났다. 근무기관 유형에 따른 주당 치료 회기 수는 20-29회기를 치료하는 경우가 $43.8 \%, 30-39$ 회기가 $37.2 \%, 40$ 회기 이상 치료하는 경우가 $19 \%$ 이었으며, 40 회기 이상 치료하는 언어재활사 중 가장 높은 비율을 차지한 근무기관은 병원(10.9\%)이었다. 논의 및 결론: 직업적 음성사용으로 인한 언어재활사의 음성피로와 음성과 관련된 삶의 질 증 진을 위해서는 주관적 음성문제에 영향을 미치는 음성오남용을 줄일 뿐 아니라 음성오남용에서 비롯되는 신체적 문제를 개선시킬 수 있는 적극적인 자가음성관리프로그램의 적용이 필요하다.

핵심어: 언어재활사, 음성피로, 음성과 관련된 삶의 질

본 연구는 2017년 언어재활사협회 역량강화사업의 지원을 받아 수행되었음.

\section{참고문헌}

강영애, 장재원, 구본석(2017). 음성장애환자 대상 음성피로와 음성평가간 상관및 음성피로도 설문(Voice Fatigue Index)의 임상적용. 대한이비인후 과학회지 두경부외과학, $60,232-242$.

김재옥, 임성은, 박선영, 최성희, 최재남, 최홍식(2007). 한국어판 음성장애지수와 음성관련 삶의 질의 타당도 및 신뢰도 연구. 말소리와 음성과학, 14, $111-125$

김지성, 최성희(2018). 한국 언어재활사들의 음성문제와 음성건강을 위한 자가관리현황. Communication Sciences \& Disorders, 23, 417-427.

송윤경, 표화영(2010). 언어치료사의 음성증상 및 한국어판 음성장애지수에 대한 예비연구. 말소리와 음성과학, 2, 123-133.

조재경(2016). 여성 텔레마케터의 직업적 음성사용에 따른 음성피로도와음향학적 특성. 대구가톨릭대학교 대학원 석사학위논문.

최성희, 최철희(2013). 초등학교 여교사들의 음성장애지수와음성오남용 특성. 말소리와음성과학, 5,53-61. 